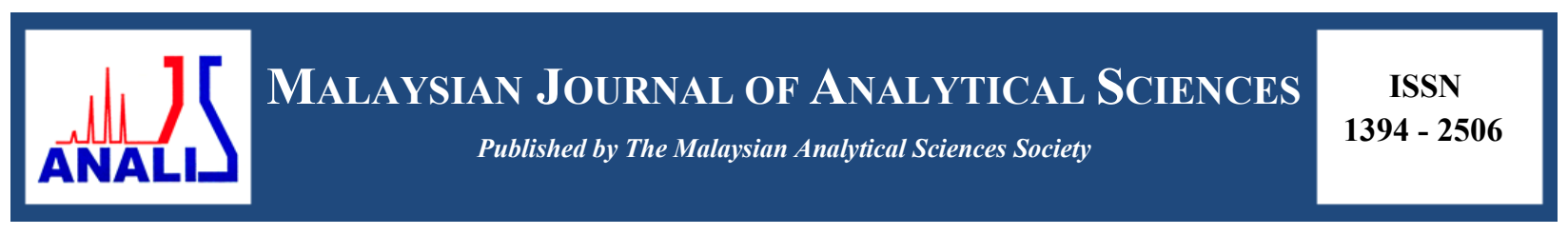

\title{
BIOSYNTHESIS OF SILVER NANOPARTICLES USING Citrus grandis PEEL EXTRACT
}

\section{(Biosintesis Nanopartikel Perak dengan Menggunakan Ekstrak Kulit Citrus grandis)}

\author{
Nur Syazana Jalani ${ }^{1}$, Wong Michell ${ }^{1}$, Wong Ee $\operatorname{Lin}^{1}$, Sharifah Zati Hanani ${ }^{1 *}$, Uda Hashim ${ }^{2}$, Rozaini Abdullah ${ }^{1}$ \\ ${ }^{1}$ Department of Chemical Engineering, Faculty of Engineering Technology, \\ Universiti Malaysia Perlis, Kampus UniCITI Alam, 02100 Sungai Chuchuh, Padang Besar, Perlis, Malaysia \\ ${ }^{2}$ Institute Nano Electronic Engineering, \\ Universiti Malaysia Perlis, 01000 Kangar, Perlis, Malaysia \\ *Corresponding author: sharifahzati@unimap.edu.my
}

Received: 16 April 2017; Accepted: 7 March 2018

\begin{abstract}
In this study, Citrus grandis or pomelo peel extract was used to synthesize silver nanoparticles (AgNPs). The effect of reaction time, amount of plant extract and concentration of silver nitrate which could influence the biosynthesis process were also studied. The synthesized AgNPs were then characterized by UV-Visible spectroscopy, Fourier transform infra-red spectroscopy (FTIR) and field emission scanning microscopy (FESEM) equipped with energy dispersive X-ray (EDX). The resulting UV-Vis spectra of synthesized AgNPs from pomelo peel extract showed standard surface plasmon resonance band in range of 401-433 nm which indicated the presence of AgNPs. FTIR spectra confirmed the existence of possible functional groups which might be responsible for the reduction of nanoparticles. Most of the synthesized AgNPs were observed in spherical shape which ranged between 20-30 $\mathrm{nm}$ under the Field Emission Scanning Electron microscope. The EDX analysis showed the strong signal at $3 \mathrm{keV}$ from the silver atoms in the synthesized nanoparticles which confirmed that the synthesis of AgNPs was successful.
\end{abstract}

Keywords: silver nanoparticles, Citrus grandis peel extract, biosynthesis, surface plasmon resonance

\begin{abstract}
Abstrak
Dalam kajian ini, ekstrak kulit Citrus grandis atau limau bali telah digunakan untuk menghasilkan nanopartikel perak. Pengaruh masa tindak balas, jumlah ekstrak kulit limau bali dan kepekatan perak nitrat ke atas biosintesis nanopartikel perak turut dikaji. Pencirian nanopartikel perak yang terbentuk kemudiannya dijalankan menggunakan spektroskopi sinar UV, spektroskopi infra merah transformasi Fourier (FTIR) dan mikroskopi imbasan pancaran medan (FESEM) dilengkapi dengan sinar-X tenaga serakan (EDX). Spektra UV-Vis nanopartikel perak dari ektrak kulit limau bali menunjukkan puncak resonansi plasmon sekitar 401-433 nm yang membuktikan pembentukan nanopartikel perak. Spektra FTIR membuktikan kewujudan beberapa kumpulan berfungsi yang mungkin terlibat dalam proses penurunan nanopartikel. Kebanyakan nanopartikel perak dilihat berbentuk sfera dan bersaiz di antara 20-30 nm melalui mikroskopi imbasan pancaran medan. Analisis EDX pula menunjukkan isyarat yang kuat daripada atom perak dalam nanopartikel yang telah disintesis dan ini membuktikan sintesis nanopartikel perak telah berjaya.
\end{abstract}

Kata kunci: nanopartikel perak, ekstrak kulit Citrus grandis, biosintesis, puncak resonansi plasmon

\section{Introduction}

Silver nanoparticles (AgNPs) have applications in various fields due to their unique optical, physical, electrical and medicinal properties. Silver nanoparticles can be incorporated into biosensor materials [1], antimicrobial applications [2], cosmetic products [3] and electronic components [4]. 
Commonly, AgNPs can be synthesized by physical, chemical and biological methods. Although physical and chemical methods may produce well-defined AgNPs, but these conventional methods have several disadvantages. These methods usually involve expensive equipment, high energy consumption and operation conditions such as temperature and pressure. Besides, utilizing hazardous chemicals as reducing agent in synthesizing AgNPs such as sodium borohydride, $\mathrm{NaBH}_{4}$ gives an adverse effect to health due to the absorption of harmful chemicals on its surface. This concern has enhanced the researchers to develop safe consumption nanoparticles and environmentally friendly processes through other biological approaches.

Recently, biosynthesis of nanoparticles has been an emerging research area which offers an alternative to conventional chemical and physical methods. The biosynthesis of AgNPs employing either microorganisms or plant extract offers an environmentally friendly process by using less toxic chemicals. However, plants are preferred because it does not involve any process of maintaining cell culture. Moreover, use of plant extracts also reduces the cost of microorganism isolation and their culture media. The synthesizing AgNPs from plant extract such as Azadirachta indica [5], Prosopis farcta [6], Peumus boldus [7] and Carica Papaya [8] have been reported extensively. Different plant showed different morphology of synthesized nanoparticles. The spherical shaped AgNPs having size in range from 4.7-11.5 nm were achieved using Azadirachta indica extract as reducing and capping agent [5]. Meanwhile, spherical AgNPs with size $10.8 \mathrm{~nm}$ was successfully synthesized from Prosopis farcta extract [6]. The reaction conditions such as amount of plant extract, concentration of silver nitrate and reaction time is important to achieve maximum number of synthesized nanoparticles. These parameters also affected the shape and size of the synthesized nanoparticles [7, 8].

Even though AgNPs have been synthesized from various plants, the synthesis of AgNPs from Citrus grandis or pomelo peel waste has been not reported. In this study, pomelo peel extract was used as natural reducing agent for the synthesis of AgNPs. This pomelo peel extract has an ability to reduce and stabilize the metallic ions. Besides, the influence of reaction time, amount of plant extract and concentration of silver nitrate on the synthesis of AgNPs were also studied.

\section{Materials}

\section{Materials and Methods}

The fresh Citrus grandis fruit was purchased from nearest stall. Silver nitrate and all chemicals (analytical grade) were purchased from Bendosen Laboratory Chemicals, Norway. All the chemicals were used as received without further purification process.

\section{Preparation of plant extract}

The pomelo peels were dried in the oven at $60{ }^{\circ} \mathrm{C}$ for 16 hours. Then, the pomelo peels were blended into fine powder and sieved [9]. The preparation of plant extract was prepared following the modified procedure from [10]. An amount $1 \mathrm{~g}$ of pomelo was dissolved in $50 \mathrm{ml}$ of distilled water and then heated at $70{ }^{\circ} \mathrm{C}$ for 30 minutes in a water bath heater. After 30 minutes, the extract was removed from the water bath heater and filtered with a filter paper.

\section{Biosynthesis of silver nanoparticles}

The AgNPs were synthesized following the procedure by Nakhjiri et al. [11] with slight modification. In a typical experiment, $10 \mathrm{ml}$ of pomelo peel extract was added to $30 \mathrm{ml}$ of $1 \mathrm{mM}$ silver nitrate solution and then kept in a water bath maintained at $70{ }^{\circ} \mathrm{C}$ for 2 hours. The formation of AgNPs were confirmed due to the colour changes of the solution. A series of experiments were conducted to investigate the effect of condition parameters including reaction time, amount of plant extract and concentration of silver nitrate. The effect of reaction time was evaluated by incubating the reaction mixtures for 1,2,3,4 and 5 hours in a water bath. The amount of plant extract was varied to $2.5,5.0,7.5,10.0$ and $12.5 \mathrm{ml}$ while the concentration of silver nitrate is constant at $1 \mathrm{mM}$. The effect of silver salt was determined by varying the concentration of silver nitrate $(0.5,2.0,4.0,6.0,8.0,10.0$ and $12.0 \mathrm{mM})$. 


\section{Characterization of synthesized silver nanoparticles}

The UV-Vis spectrometer (Shimadzu, Model UV-1800 spectrophotometer) was used to measure the absorption spectra of the synthesized AgNPs against distilled water as blank. The absorbance of solution was recorded after diluting a small aliquot $(0.5 \mathrm{ml})$ of sample with $5 \mathrm{ml}$ deionized water.

FTIR analysis was carried out after the removal of the free biomass residue or compound that was not absorbed by repeated centrifugation and redispersion in water. Thereafter, the purified suspension was dried in hot air oven at 60 ${ }^{\circ} \mathrm{C}$ for 10-15 minutes. Finally, the dried nanoparticles were analyzed by FTIR spectrophotometer (Perkin Elmer) and the spectra was scanned in the range of $4000 \mathrm{~cm}^{-1}$ to $650 \mathrm{~cm}^{-1}$. The sample was dispersed uniformly in a matrix of dry $\mathrm{KBr}$ and then compressed to form a clear disc which then examined directly.

The morphology of the synthesized AgNPs was determined using FESEM-EDX (Model FEI Nova NanoSEM 450) at the NOR Laboratory in University Science Malaysia by coating the nanoparticles with a fine layer of platinum and placed in the FESEM-EDX to view its surface image.

\section{Visual observation and UV-Vis spectroscopy}

\section{Results and Discussion}

The early prediction of the AgNPs formation by reduction of silver nitrate and pomelo peel extract can be observed by colour change of the mixture. The change of colour from colourless to yellowish-brown solution as shown in Figure 1 indicates the presence of AgNPs in the reaction mixture. The increase in colour intensity of reaction mixture could be due to increasing number of nanoparticles formed because of reduction of silver ions present in the aqueous solution. It is known that AgNPs appear yellowish-brown colour due to the excitation of the surface plasmon vibrations [12]. The surface plasmon resonance (SPR) phenomenon occurs when noble metal nanoparticles emit strong electromagnetic fields on the particle surface thus enhancing its radiative properties [13]. This leads to a strong absorption band at about 400-500 nm in UV-Vis spectra of AgNPs [14].

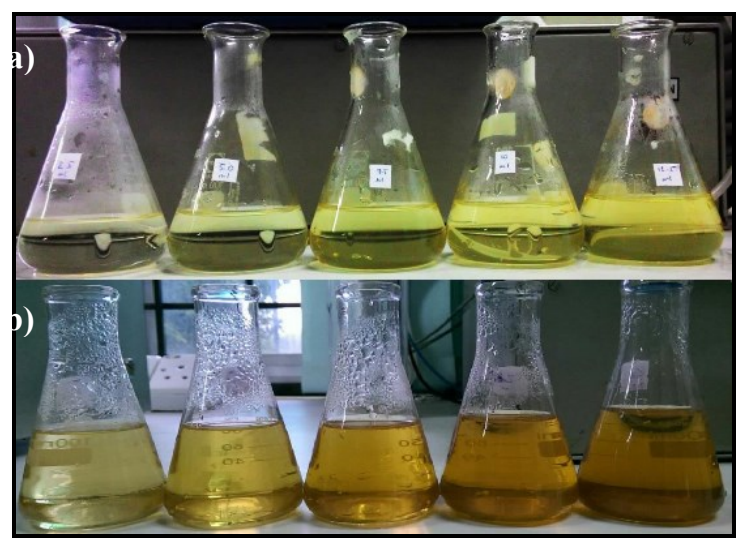

Figure 1. The colour of mixture reaction (a) before and (b) after the reaction

\section{Effect of pomelo peel extract amount}

Figure 2 shows the UV-Vis spectra of the synthesized AgNPs at different amount of pomelo peel extract from 2.5 $\mathrm{ml}$ to $12.5 \mathrm{ml}$. The UV-Vis spectra of synthesized AgNPs at pomelo peel extract from $5.0 \mathrm{ml}$ to $12.5 \mathrm{ml}$ showed the SPR peak obtained ranged from $401.6 \mathrm{~nm}$ to $407.6 \mathrm{~nm}$ as a result of silver plasmon resonance which confirmed the formation of AgNPs. The increase of pomelo peel extract results in increase of SPR intensity and the SPR band shifted to longer wavelength. The increase in intensity could be due to increasing number of nanoparticles formed because of reduction of silver ions present in the aqueous solution. Meanwhile the SPR band shifted to longer wavelength may be due to the amount of reducing agents found in the reaction mixture. As the amount of pomelo peel extract increases, more reducing agents are available. From Figure 2, the $12.5 \mathrm{ml}$ of pomelo peels extract gave the highest SPR intensity where the reducing agent bounds itself to the surface of $\mathrm{Ag}^{+}$and reduces it to $\mathrm{Ag}^{0}$ [15]. 
Meanwhile, no peak was observed at $2.5 \mathrm{ml}$ of pomelo peel extract. This is due to insufficient of reducing agent to complete the formation of AgNPs.

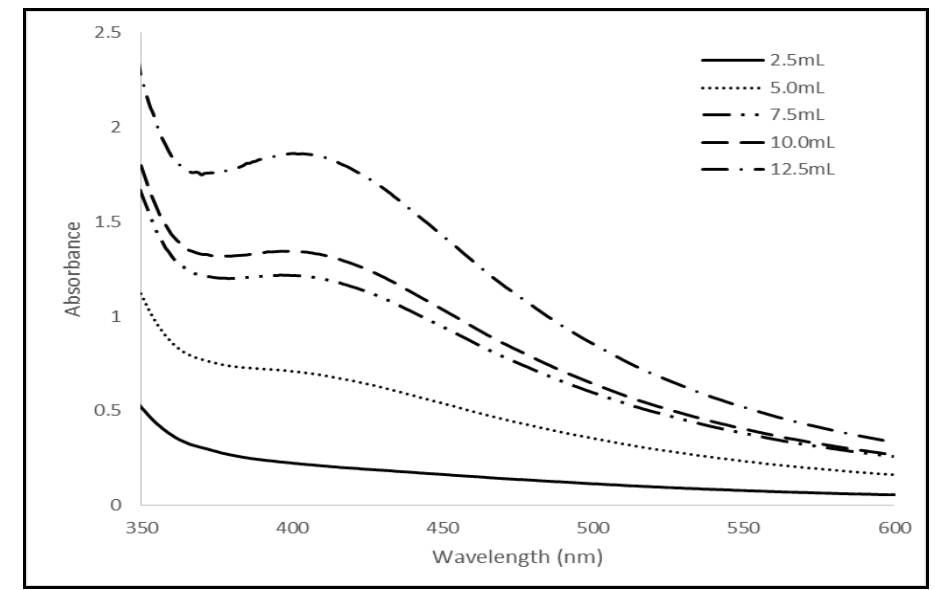

Figure 2. UV-Vis spectra of AgNPs synthesized at for various pomelo peel extract amount (Constant parameter: $1 \mathrm{mM} \mathrm{AgNO} 3,70^{\circ} \mathrm{C}, 2$ hours)

\section{Effect of silver nitrate concentration}

The UV-Vis spectra in Figure 3 shows the AgNPs were synthesized at different silver nitrate concentration. The SPR wavelengths vary from the range of $406 \mathrm{~nm}$ to $422 \mathrm{~nm}$ as the concentration silver nitrate increased from $1 \mathrm{mM}$ to $5 \mathrm{mM}$. It was observed that as the concentration of silver nitrate increases, the SPR band shifts to the longer wavelength. This may suggest high concentrations of silver nitrate $(3 \mathrm{mM}$ to $5 \mathrm{mM})$ may cause the formation of large nanoparticles [16]. The highest SPR intensity can be observed at $2 \mathrm{mM}$ of silver nitrate. However, as the concentration further increase to $5 \mathrm{mM}$, the SPR intensity decreases. This phenomenon may occur due to the limited availability of functional groups in the pomelo peels extract to act as reducing agents [17]. Although the availability of silver ions for aggregation is high, the limited amount of reducing agent prevents the formation of AgNPs.

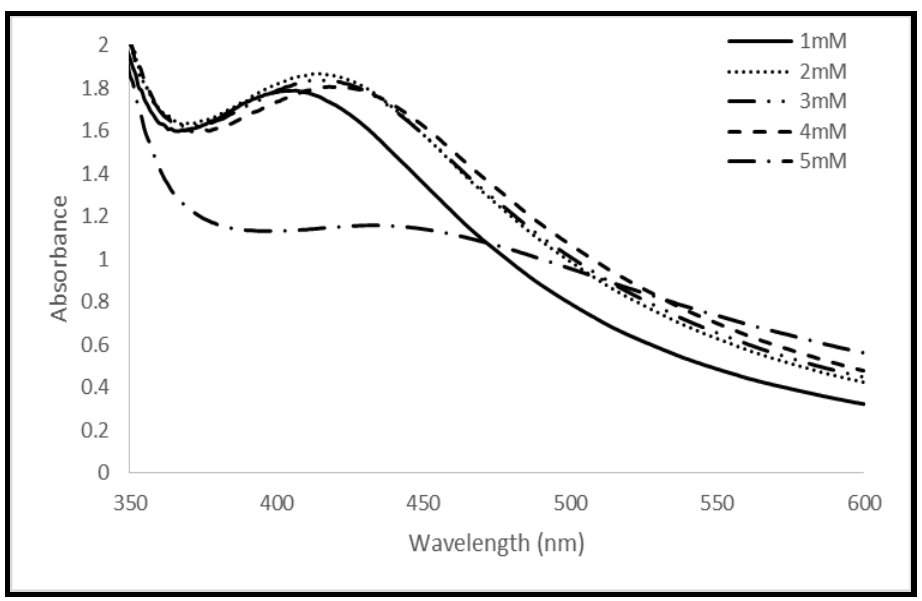

Figure 3. UV-Vis spectra of AgNPs at different concentration of silver nitrate (Constant parameter: $10 \mathrm{ml}$ pomelo peel extract, $70{ }^{\circ} \mathrm{C}, 2$ hours) 


\section{Effect of reaction time}

The UV-Vis spectra of synthesized AgNPs as shown in Figure 4 was synthesized at different reaction time. The SPR wavelength ranging from $401 \mathrm{~nm}$ to $415 \mathrm{~nm}$ as the reaction time increased from 1 hour to 5 hours. The SPR peak appeared at about $401 \mathrm{~nm}$ at the first hour and slowly shifts to the longer wavelength with increasing reaction time. The intensity of the SPR peak increased as the reaction time increased, which indicated the increased formation of the synthesized AgNPs. The increase in SPR intensity might be due to the transformation of $\mathrm{OH}$ groups to carbonyl groups because of silver ions reduction [18].

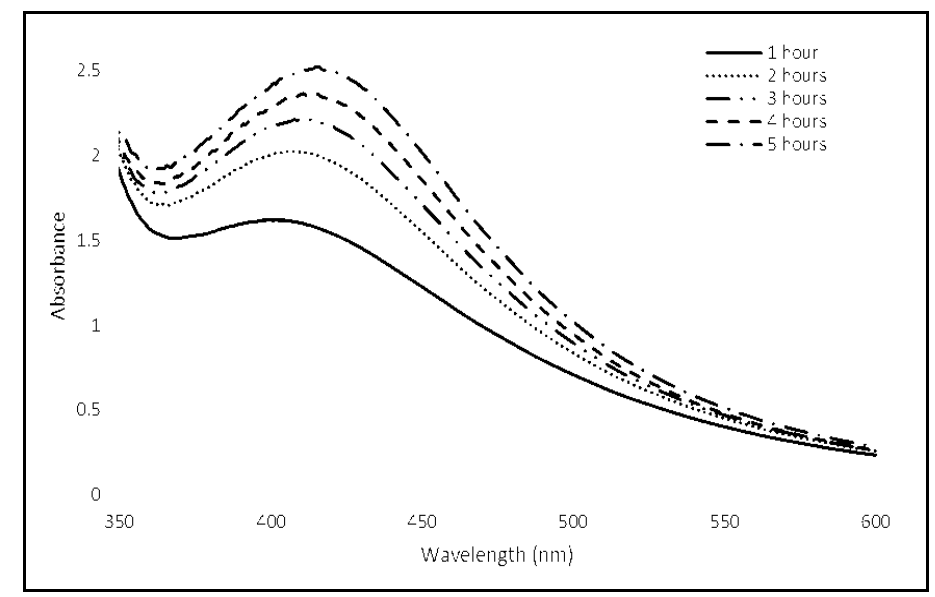

Figure 4. UV-Vis spectra of AgNPs at different reaction time (Constant parameter: $1 \mathrm{mM} \mathrm{AgNO}_{3}, 10 \mathrm{ml}$ pomelo peel extract, $70^{\circ} \mathrm{C}$ )

\section{FTIR analysis}

The FTIR analysis was carried out to identify the major functional groups in pomelo peel and their possible involvement in AgNPs synthesis. Table 1 shows the shifting of peaks of peel extract which may suggest the involvement of the functional group in the formation of AgNPs. First, the shifting of the peak could be observed from $3357.90 \mathrm{~cm}^{-1}$ to $3380.21 \mathrm{~cm}^{-1}$ which is corresponds to H-bonded alcohols and phenols. Another shift is observed in peak from $1607.93 \mathrm{~cm}^{-1}$ to $1641.77 \mathrm{~cm}^{-1}$ which correspond to $\mathrm{C}=\mathrm{C}$ of alkenes and $\mathrm{C}=\mathrm{N}$ amine stretching. The shifting of these peaks indicates these functional groups might involve in the synthesis of AgNPs. Meanwhile, the observed peak at $1051.29 \mathrm{~cm}^{-1}$ denote $-\mathrm{C}-\mathrm{OC}$ linkages and $-\mathrm{C}-\mathrm{O}$ bonds which mainly attributed from flavonoids and terpenoids in pomelo peel extract [19]. The disappearance of these peaks in FTIR spectra of AgNPs suggest the involvement of these bioactive compounds in reducing silver ions to AgNPs.

Table 1. FTIR peak assignments of pomelo peel and synthesized AgNPs

\begin{tabular}{llc}
\hline Assignment & Pomelo Peel & AgNPs \\
\hline H-bonded alcohols and phenols & $3357.90 \mathrm{~cm}^{-1}$ & $3380.21 \mathrm{~cm}^{-1}$ \\
$\mathrm{C}=\mathrm{C}$ of alkenes and C=N amine stretching & $1607.93 \mathrm{~cm}^{-1}$ & $1641.77 \mathrm{~cm}^{-1}$ \\
C-N stretching and C-O stretching of amino & $1051.29 \mathrm{~cm}^{-1}$ & - \\
and carboxyl groups & & \\
\hline
\end{tabular}

Condition of synthesized AgNPs: $2 \mathrm{mM} \mathrm{AgNO}_{3}, 12.5 \mathrm{ml}$ pomelo peel extract, 5 hours

\section{FESEM-EDX analysis}

The surface morphology of nanoparticles and their chemical composition was investigated using FESEM-EDX. Figure $5 \mathrm{a}$ and $5 \mathrm{~b}$ show that most of the synthesized AgNPs are found to be in spherical shape and some are irregular which the size range between 20-30 $\mathrm{nm}$. The aggregation of the synthesized AgNPs may be caused by cell 
components present on the nanoparticles surface that acts as a capping agent [20]. The EDX profile in Figure 5c shows a spectral signal in silver region $(\mathrm{Ag})$ approximately at $3 \mathrm{keV}$ which corresponded to the absorption of metallic silver due to SPR of AgNPs [21]. The others signal from $\mathrm{Cl}, \mathrm{C}, \mathrm{O}, \mathrm{N}$ and $\mathrm{S}$ atoms are also recorded which might be attributed to pomelo peel extract used.
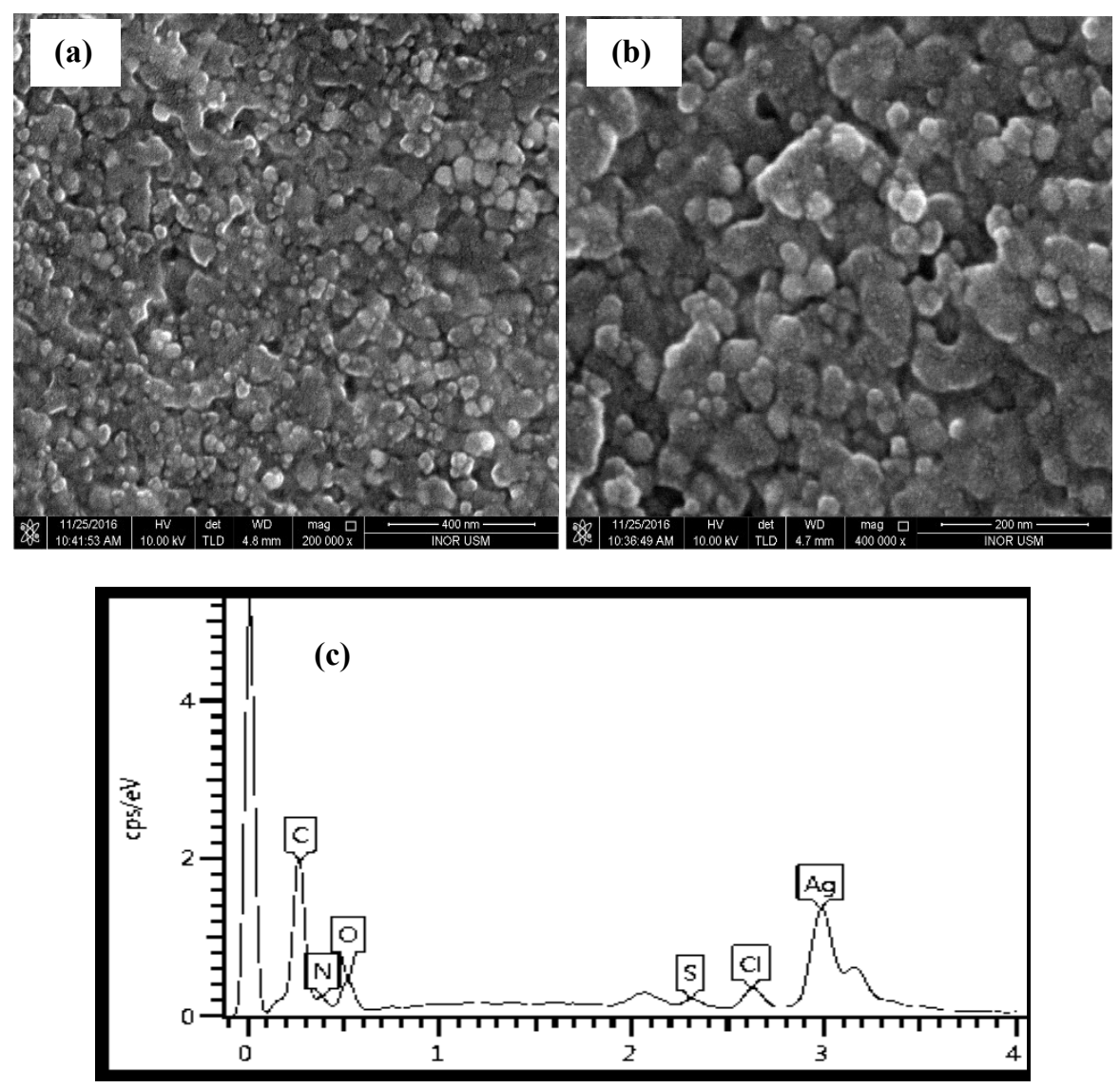

Figure 5. FESEM image of synthesized AgNPs at various resolutions (a) 200,000x, (b) 400,000x and (c) EDX profile showing the chemical composition (Condition of synthesized AgNPs: $2 \mathrm{mM} \mathrm{AgNO}, 12.5 \mathrm{ml}$ pomelo peel extract, 5 hours)

\section{Conclusion}

The spherical and irregular AgNPs with size ranging from 20-30 nm were successfully synthesized using pomelo peel extract as reducing agent. The experiment done showed that parameters studied do affect the biosynthesis of AgNPs as the time and amount of peel extract was directly proportional to the number of AgNPs formed. In contrast, the number of AgNPs formed was inversely proportional to the concentration of silver nitrate.

\section{Acknowledgement}

This work has been supported by Ministry of Higher Education through research grant (FRGS 9003-00509). The authors were gratefully acknowledged Faculty of Engineering Technology and Institute of Sustainable Agrotechnology, Sungai Chuchuh for providing facilities to carry out this research. The author also appreciatively acknowledged Institute Nano Electronic Engineering for facilities and consultation support. 


\section{References}

1. Ahmed, S., Ahmad, M., Swami, B. L. and Ikram, S. (2014). A review on plants extract mediated synthesis of silver nanoparticles for antimicrobial applications: A green expertise. Journal of Advanced Research, 7(1): 1728.

2. Kotakadi, V. S., Rao, Y. S., Gaddam, S. A., Prasad, T. N. V. K. V, Reddy, A. V. and Gopal, S. V. R. S. (2013). Simple and rapid biosynthesis of stable silver nanoparticles using dried leaves of Catharanthus roseus. Linn. G. Donn and its antimicrobial activity. Colloids and Surfaces B: Biointerfaces, 105: 194-198.

3. Malik, P., Shankar, R., Malik, V., Sharma, N. and Mukherjee, T. K. (2014). Green chemistry based benign routes for nanoparticle synthesis. Journal of Nanoparticles, 2014: 1-14.

4. Sathyavathi, R., Krishna, M. B., Rao, S. V., Saritha, R. and Narayana Rao, D. (2010). Biosynthesis of silver nanoparticles using Coriandrum sativum leaf extract and their application in nonlinear optics. Advanced Science Letters, 3(2): 138-143.

5. Nazeruddin, G. M., Prasad, N. R., Waghmare, S. R., Garadkar, K. M. and Mulla, I. S. (2014). Extracellular biosynthesis of silver nanoparticle using Azadirachta indica leaf extract and its anti-microbial activity. Journal of Alloys and Compounds, 583: 272-277.

6. Miri, A., Sarani, M., Rezazade Bazaz, M. and Darroudi, M. (2015). Plant-mediated biosynthesis of silver nanoparticles using Prosopis farcta extract and its antibacterial properties. Spectrochimica Acta - Part A: Molecular and Biomolecular Spectroscopy, 141: 287-291.

7. Sanchez, G. R., Castilla, C. L., Gomez, N. B., Garcia, A., Marcos, R. and Carmona, E. R. (2016). Leaf extract from the endemic plant Peumus boldus as an effective bioproduct for the green synthesis of silver nanoparticles. Materials Letters, 183: 255-260.

8. Kokila, T., Ramesh, P. S. and Geetha, D. (2016). Biosynthesis of AgNPs using Carica papaya peel extract and evaluation of its antioxidant and antimicrobial activities. Ecotoxicology and Environmental Safety, 134: 467473.

9. Zarina, Z. and Tan, S. Y. (2013). Determination of flavonoids in Citrus grandis (Pomelo) peels and their inhibition activity on lipid peroxidation in fish tissue. International Food Research Journal, 20(1): 313-317.

10. Nayak, D., Ashe, S., Rauta, P. R., Kumari, M. and Nayak, B. (2016). Bark extract mediated green synthesis of silver nanoparticles: Evaluation of antimicrobial activity and antiproliferative response against osteosarcoma. Materials Science and Engineering C, 58(1): 44-52.

11. Nakhjiri, F., Mirhosseini, M. and Mozaheb, M. A. (2013). Green synthesis of silver nanoparticles using olive leaf extract and its antibacterial activity. Nanomedical Journal, 4(2): 98-106.

12. Vasireddy, R., Paul, R. and Krishna, A. (2012). Green synthesis of silver nanoparticles and the study of optical properties. Nanomaterial Nanotechnology, 2: 1-6.

13. Huang, X. and El-Sayed, M, A. (2010). Gold nanoparticles: Optical properties and implementations in cancer diagnosis and photothermal therapy. Journal of Advanced Research, 1(1): 13-28.

14. Senthamilselvi, S., Kumar, P., Prabha, A. L. and Govindaraju, M. (2013). Green simplistic biosynthesis of antibacterial silver nanoparticles using Annona Squamosa leaf extract. Nano Biomedical Engineering, 5(2): 102106.

15. Yang, N. and Li, W. (2013). Mango peel extract mediated novel route for synthesis of silver nanoparticles and antibacterial application of silver nanoparticles loaded onto non-woven fabrics. Industrial Crops and Products, 48: 81- 88 .

16. Bar, H., Bhui, D. K., Sahoo, G. P., Sarkar, P., Pyne, S. and Misra, A. (2009). Green synthesis of silver nanoparticles using seed extract of Jatropha curcas. Colloids and Surfaces A: Physicochemical and Engineering Aspects, 348(1): 212-216.

17. Mansouri, S. S. and Ghader, S. (2009). Experimental study on effect of different parameters on size and shape of triangular silver nanoparticles prepared by a simple and rapid method in aqueous solution. Arabian Journal of Chemistry, 2(1): 47-53.

18. Ahmad, B., Ali, J. and Bashir, S. (2013). Optimization and effects of different reaction conditions for the bioinspired synthesis of silver nanoparticles using Hippophae rhamnoides Linn. leaves aqueous extract. World Applied Sciences Journal, 22(6): 836-843.

19. Ahmed, S., Ullah, S., Ahmad, M. and Swami, B. L. (2015). Green synthesis of silver nanoparticles using Azadirachta indica aqueous leaf extract. Journal of Radiation Research and Applied Sciences, 9(1): 1-7. 
20. Vanaja, M. and Annadurai, G. (2012). Coleus aromaticus leaf extract mediated synthesis of silver nanoparticles and its bactericidal activity. Applied Nanoscience, 3(3): 217-223.

21. Prabakar, K., Sivalingam, P., Mohamed Rabeek, S. I., Muthuselvam, M., Devarajan, N., Arjunan, A. and Wembonyama, J. P. (2013). Evaluation of antibacterial efficacy of phyto fabricated silver nanoparticles using Mukia scabrella (Musumusukkai) against drug resistance nosocomial gram negative bacterial pathogens. Colloids and Surfaces B: Biointerfaces, 104: 282-288. 